Canadian

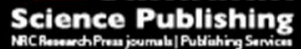

Canadian Journal of Forest Research Revue canadienne de recherche forestière

\title{
A multi-scale analysis of the effects of alternative silvicultural treatments on windthrow within balsam fir dominated stands
}

\begin{tabular}{|r|l|}
\hline Journal: & Canadian Journal of Forest Research \\
\hline Manuscript ID & cjfr-2015-0221.R1 \\
\hline Manuscript Type: & Article \\
\hline Date Submitted by the Author: & 11 -Aug-2015 \\
\hline Keyword: & $\begin{array}{l}\text { Anyomi, Kenneth; Université Laval, Département des sciences du bois et } \\
\text { de la forêt; University of British Columbia, Forest and Conservation } \\
\text { Ruel, Jean-Claude; Universit } \vartheta \text { Laval }\end{array}$ \\
\hline & \\
\hline
\end{tabular}

\section{SCHOLARONE ${ }^{\text {Tw }}$}

Manuscripts 
6 Centre d'Étude de la Forêt. Faculté de foresterie, de géographie et de géomatique,

7 Université Laval, 2405 rue de la Terrasse, Québec, QC, G1V 0A6, Canada

$8 \quad$ * Correspondence author;

$9 \quad$ E-mail; kenneth-agbesi.anyomi.1@ulaval.ca

10 


\section{Abstract}

23 Boreal ecosystem functioning is largely controlled by disturbance dynamics. There have

24 been efforts at adapting forest management approaches to emulate natural disturbance

25 effects as this is expected to maintain ecosystem resilience. In many instances, this

26 involves resorting to partial cutting strategies that are likely to increase windthrow losses.

27 The objective of this study was to determine the effects of alternative silvicultural

28 practices on windthrow damage and how these effects vary with the scale of treatment.

29 The study was conducted in the Quebec north shore region (Canada), an area dominated

30 by balsam fir (Abies balsamea (L.) Mill.) accompanied by black spruce (Picea mariana

31 (Mill) B.S.P.). Four different silvicultural treatments (overstory removal, heavy partial

32 cutting, and two patterns of selection cutting) and control areas were implemented in

332004 and 2005. The experiment used a nested approach where treatment at the plot level

34 was independent and yet nested within block-level treatment. At the block level,

35 treatments were applied over 10-20 ha units, leaving a small portion of the block for a

36 smaller application of each treatment $\left(2500 \mathrm{~m}^{2}\right.$, plot scale). Inventory was carried out

37 before harvesting and monitoring was done yearly after harvesting, with the aim to better

38 understand the plot- and block-level factors that drive windthrow damage levels and the

39 effects of alternative silvicultural treatments. Results after 6-7 years show that, basal area

40 proportion windthrown differs substantially between treatments as well as when treated

41 sites were compared to control sites. Windthrow levels were higher under heavy cuts

42 relative to selection cuts and also increased with balsam fir proportion. Windthrow

43 proportions were better correlated to block-level treatment than plot-level treatment 
44 showing that the environment surrounding the treated plot can have an important effect 45 on windthrow losses. Overall, selection cutting system particularly SC2, retains most 46 green-tree basal area and thus best meets the management objective of retaining old-

47 growth attributes. A simple empirical model was calibrated which could aid in hazard 48 rating.

49 Keywords: multi-scale, balsam fir, back spruce, partial cutting, windthrow, empirical 50 model 


\section{Résumé}

53 Le fonctionnement des écosystèmes forestiers boréaux est largement régi par la

54 dynamique naturelle des perturbations. Devant ce constat, des efforts ont été consentis

55 afin de développer des approches d'aménagement s'inspirant des perturbations naturelles

56 en vue d'assurer la résilience des écosystèmes. Dans bien des cas, ceci implique un

57 recours accru aux coupes partielles mais celles-ci sont susceptibles d'augmenter les

58 pertes par chablis. L'objectif de cette étude était de déterminer les effets de pratiques

59 sylvicoles alternatives sur les pertes par chablis, en tenant compte de l'échelle

60 d'application du traitement. L'étude s'est déroulée dans la région de la Côte-Nord du

61 Québec (Canada). La forêt était dominée par le sapin baumier (Abies balsamea (L.) Mill.)

62 accompagné de l'épinette noire (Picea mariana (Mill) B.S.P.). Quatre traitements

63 sylvicoles (coupe avec protection de la régénération, coupe partielle forte, deux patrons

64 de jardinage) et un témoin ont été implantés en 2004 et 2005. L'étude fait appel à un

65 dispositif niché où l'application à l'échelle fine de la parcelle est indépendante de celle à

66 l'échelle du bloc. A l'échelle du bloc, les traitements ont été appliqués sur des surfaces de

67 10-20 ha. Une petite portion de chaque bloc a été réservée pour une application de chaque

68 traitement à une échelle plus fine (parcelle, $2500 \mathrm{~m}^{2}$ ). Des parcelles permanentes ont été

69 établies avant la coupe et suivies annuellement en vue de mieux comprendre l'effet de

70 l'application des traitements à diverses échelles, ainsi que l'effet des variables de

71 peuplement susceptibles d'influencer le niveau de pertes. Les résultats après 6-7 ans

72 montrent que la proportion de surface terrière en chablis varie fortement selon les

73 traitements. Les pertes par chablis augmentaient avec l'intensité du prélèvement et avec

74 la proportion de surface terrière en sapin. Les pertes par chablis étaient davantage 
75 expliquées par le traitement appliqué à l'échelle du bloc qu'à celui de la parcelle. Ceci 76 indique que l'environnement autour de la parcelle traitée joue un rôle majeur sur 77 l'ampleur des pertes. En somme, le système de coupe de jardinage (notamment SC2)

78 maintient la surface terrière la plus élevée et conserve ainsi mieux les attributs des vieilles

79 forêts. Un modèle empirique simple a été paramétré et pourrait servir à évaluer le risque 80 de chablis selon le type de coupe.

81 Keywords: multi-échelle, sapin baumier, épinette noire, coupe partielle, chablis, modèle

82 empirique.

83 


\section{$84 \quad$ Introduction}

85 In forest management, natural disturbances are becoming a model from which to design

86 silvicultural strategies (Long 2009; Bose et al. 2014). Over much of the boreal forest, fire

87 is considered the predominant mode of disturbance that shapes forest structure and

88 composition (Stocks et al. 2003). However, in regions subject to a maritime influence,

89 secondary types of disturbance (such as wind) become the predominant causes of the

90 rarer disturbance events that do happen, and because these occur at longer intervals than

91 fire, a larger fraction of the landscape reaches old-growth stages. Such a situation occurs

92 in eastern Quebec where the fire cycle can exceed 500 years and where irregular and

93 uneven-aged stands dominate the landscape (Bouchard et al. 2008). Traditionally, a

94 harvesting strategy that protects advanced regeneration (CPRS) has been the standard

95 harvest method in this region. However, when applied in irregular stands, this approach

96 greatly simplifies forest structure. An alternative treatment that keeps small merchantable

97 stems has been implemented in eastern Canada (Groot et al. 2005) but it still has a major

98 impact on stand structure (Cimon-Morin et al. 2010). To minimize the impact of

99 harvesting, lighter forms of partial cutting should also be considered (Ruel et al. 2013).

100 An increased use of partial cutting is however limited by the fear of windthrow. This is

101 particularly relevant in previously unmanaged, old growth forests (Ruel 1995). The

102 natural disturbance regime of eastern Quebec is influenced by partial windthrow

103 (Waldron et al. 2013) and partial cutting is likely to increase the occurrence of windthrow

104 through an increase of wind penetration into the stand (Gardiner et al. 1997). This

105 increase in windthrow risk will vary depending on landscape, site and stand

106 characteristics (Ruel 1995). At the landscape scale, topographic factors have been shown 
107 to play a major role, creating strong variations in wind speed over short distances (Ruel et 108 al. 1998). Topex to distance, an index of topographic exposure, has been shown to be 109 closely related to these wind speed variations (Ruel et al. 1997). An increase in wind 110 speed with elevation has also been observed (Ruel 1995). Site factors that affect 111 anchorage strength, such as soil depth and drainage, are well known to have an impact on 112 the risk of windthrow (Ruel 1995). At the stand level, species composition, height, 113 density and age can all have an effect (Ruel 1995). Balsam fir (Abies balsamea (L.) Mill.) 114 has been shown to be more vulnerable than black spruce (Picea mariana (Mill.) B.S.P.) 115 (Ruel 2000) and vulnerability generally increases with height (Ruel 1995). Stand 116 structure has also been suggested to influence the risk of windthrow, uneven-aged stands 117 being perceived to be less at risk (Mason 2002; Boucher et al. 2006). The intensity and 118 the nature of the partial harvest will influence the amount of windthrow, more intensive 119 cuts leading to greater windthrow. Finally, in addition to the characteristics of the stand 120 itself and the treatment applied, those of adjacent stands can also have an important effect 121 (Ruel et al. 2003). Given the complexity of these influencing factors, it becomes very 122 difficult to predict mortality after partial cutting.

123 Because influential factors act at different scales, a good understanding of the impact of 124 partial cutting requires an approach that considers various scales (Ruel 2000). This study 125 adopts such an approach in examining partial cutting after windthrow in Eastern Quebec.

126 A range of harvesting intensities and patterns are examined in a nested experimental

127 design with the objective to determine: 1) the influence of alternative silvicultural 128 practices on windthrow damage; 2) the role of scale of treatment (block vs plot) on 129 windthrow damage; 3) how site factors interact with treatment in driving windthrow 
130 damage, and finally 4) calibrate empirical models that could assist managers in hazard

131 rating.

\section{$132 \quad 2.0$ Materials and Methods}

\section{$133 \quad 2.1$ Study Site}

134 The study area spanned from latitude $50{ }^{0} \mathrm{~N}$ to $51{ }^{0} \mathrm{~N}$ and longitude $67{ }^{0} \mathrm{~W}$ to $69{ }^{0} \mathrm{~W}$. This

135 area is part of the eastern black spruce-feathermoss bioclimatic domain dominated by

136 black spruce and balsam fir. Being subjected to a maritime influence, the fire cycle is

137 rather long, reaching more than 500 years in the eastern part of the region (Bouchard et al.

138 2008). In this context, stands are able to reach uneven-aged or irregular structures

139 (Bergeron et al. 2007). Such structures represent over $60 \%$ of the unharvested area in the

140 study region and are largely maintained through partial disturbances (Boucher et al.

141 2003). Partial windthrow (25-75\% basal area damaged) has been shown to play a

142 significant role in the region, impacting areas similar to fire over a thirty year period

143 (Waldron et al. 2013). An analysis of photo-interpreted forest maps produced by the

144 Quebec Ministry of Natural Resources (MRN) during its third inventory program

145 (Létourneau et al. 2003) reveals that the area is dominated by coarse deposit types of

146 mainly glacial origin and drainage is predominantly moderate. Available data for the

147 period 1950 to 2000 show that annual mean temperature for the region ranges from $-4{ }^{\circ} \mathrm{C}$

148 to $1.5^{\circ} \mathrm{C}$. The area receives a mean annual total rainfall of $993 \mathrm{~mm}(\mathrm{sd} .130 \mathrm{~mm})$ and

149 mean snowfall of $398 \mathrm{~mm} \mathrm{year}^{-1}\left(\mathrm{sd} .74 \mathrm{~mm} \mathrm{year}^{-1}\right)$. Mean wind speed for the area

150 ranges from $15 \mathrm{~km} /$ hour to $17 \mathrm{~km} /$ hour (BioSIM model ver. 8, Régnière and Saint-Amant, 151 2008). 


\section{$152 \quad 2.2$ Experimental design}

153 The study region is composed of four sites, namely Arbec (A), Abitibi site-1 (AB1),

154 Abitibi site-2 (AB2) and Kruger (K). Study sites were located in areas dominated by

155 stands over 120 years old, presenting an irregular or uneven-aged structure typical of the

156 region and for which alternatives to clearcutting would be sought. Each site has five

157 blocks, each 10 to 20 ha (Fig. 1A and 1B).

$158<<<$ Fig. $1>>>$

159 The experimental design includes a nested application of silvicultural treatments. One of

160 five silvicultural treatments was randomly assigned to each block, reserving a small

161 portion of the block for a small scale application of each treatment. At this finer scale,

162 treatments were randomly applied on $2500 \mathrm{~m}^{2}$ units, leaving a $15 \mathrm{~m}$ buffer zone receiving

163 the same treatment around each permanent plot. To ensure that the finer scale treatment

164 was indeed different from the block treatment application, trees to cut were marked

165 within the smaller units.

166 Treatments include an uncut control, two heavy cut types, and two selection cut variants.

167 The first heavy cut type involves the harvesting of merchantable trees $(>9 \mathrm{~cm} \mathrm{dbh})$ but

168 with protection of advanced regeneration (CPRS); this is similar to the overstory removal

169 in a shelterwood system and is the current silvicultural technique applied on most

170 commercial forests in the region. It only leaves a few residual trees removing about $90 \%$

171 of total basal area. The second heavy cut type involves the removal of all trees of

172 diameter $14 \mathrm{~cm}$ and above (Groot et al. 2005); this is a kind of heavy partial cutting

173 system removing about $70 \%$ of total basal area, and is currently practiced in Ontario and

174 Quebec (CPPTM) with the objective to create a two-story or irregular stand structure; 
175 skid trail spacing is left to the harvester operator and is largely governed by the reach of

176 the equipment. The first variant of selection cutting leads to an intensive removal (50\% of

177 basal area) close to skid trail (within $5 \mathrm{~m}$ ) but leaving a strip of intact canopy between

178 skid trails at the first cutting cycle. At the next rotation, harvesting is carried out in areas

179 adjacent $(5 \mathrm{~m})$ to a new skid trail established within the previously intact strip (SC1). In

180 the second variant, permanent primary skid trails are established every $35 \mathrm{~m}$ and

181 secondary skid trails, perpendicular to the main trails provide access to the rest of the

182 stand where $25 \%$ of basal area is removed (SC2). The two selection cutting systems are

183 similar in that they both eventually remove $35 \%$ of stand basal area, the major difference

184 being in the harvesting pattern. With both approaches, an optimisation procedure was

185 used to define the target residual structure and hence the planned harvest. Small

186 merchantable stems (10-12 cm DBH) were not targeted for removal except in skid trails.

187 Since the intent was to preserve the old forest attributes, including species composition,

188 no species was prioritized for harvesting. Harvesting was carried out in the summer of

1892004 at the AB1 and Kruger sites and in 2005 at the AB2 and Arbec sites. Additional

190 details on the treatment development and implementation can be found in Ruel et al.

$191 \quad(2007,2013)$

192 Windthrow was monitored using a network of permanent plots established prior to

193 cutting. A $400 \mathrm{~m}^{2}$ plot was established at the center of each of the small scale treatment

194 unit $\left(2500 \mathrm{~m}^{2}\right)$. Three additional plots were randomly allocated to the remaining portion

195 of the block, corresponding to the larger scale treatment application (Fig. 1). Due to

196 logistical difficulties, there were some departures from this sampling pattern. Within site

197 AB2, blocks had 4 plots each, with no smaller scale application of treatments. Within one 
198 of the blocks in Kruger, an additional plot was established in the larger scale application 199 of the treatment. There was therefore a total of 141 study plots, 40 located at the AB1 200 study site, 41 in Kruger, 40 in Arbec and 20 in AB2. Overall, there were 28 permanent 201 plots under each of the treatments (except CPRS which had 29 plots) (Table 1).

$202<<<$ Table $1>>>$

\section{$203 \quad 2.3$ Site monitoring}

204 Inventory was carried out before harvesting in which all merchantable trees were counted

205 by $2 \mathrm{~cm} \mathrm{DBH}$ classes. Monitoring was repeated after the harvesting and every year

206 following the harvesting until 2011 (6-7 years after harvesting) by identifying and

207 distinguishing uprooted trees, broken as well as standing dead trees.

\section{$208 \quad 2.4$ Modelling windthrow}

\section{$209 \quad$ 2.4.1 Explanatory variables}

210 Species composition is a common factor influencing the amount of windthrow after 211 partial cutting. We therefore verified the effects of basal area proportion of black spruce, 212 balsam fir, white birch (Betula papyrifera Marsh.) and white spruce (Picea glauca 213 (Moench) Voss) on windthrow damage. Because stem (and tree) mass is principally a 214 function of tree diameter and height and correlates highly with critical turning moment 215 (the force required to either uproot or break trees) (Elie and Ruel 2005), diameter and 216 height were tested as predictors. Height was estimated using equations from Fortin et al. 217 (2009). We also verified the effects of structural diversity measured with Shannon 218 evenness index (Boucher et al. 2006; Anyomi et al. 2013) on windthrow damage. 219 Shannon evenness index was estimated with Eqn. 1 below;

$220[1] S_{h}=-\sum_{i=1}^{s} p_{i} \ln \left(p_{i}\right)$ 
221 Where $p_{i}$ is basal area proportion of a diameter class $i$ relative to total stand basal area, $s$

222 is number of diameter classes.

223 Finally, a site may be more vulnerable to windthrow owing to its elevation and exposure

224 to wind. Data were therefore obtained on elevation and topographical exposure to wind

225 (topex). To calculate Topex values, a digital elevation model with a grid size of $100 \mathrm{~m}$

226 was developed from topographic maps with an equidistance with 20-m contour lines.

227 From this grid, Topex values were calculated using a routine developed by Ruel et al.

228 (2002). Table 2 has the major variables considered in this modelling exercise.

$229<<<$ Table $2>>>$

\section{$230 \quad$ 2.4.2 Quantifying windthrow}

231 Windthrow damage is defined in this study as the proportion of plot total basal area

232 damaged, including broken and uprooted trees (Eqn. 2).

233

[2] $W=\left(\frac{\sum_{i=1}^{n} G_{w, i}}{G_{T}}\right) * 100$

234 Where $W$ is windthrow damage, $\sum_{i=1}^{n} G_{w, i}$ is the sum of basal area $\left(G_{w, i}\right)$ of all damaged

235 trees $i$ to $n$ on a plot and $G_{T}$ is total plot basal area before logging.

236 Windthrow damage was compared for treated (CPRS, CPPTM, SC1 \& SC2) and non237 treated (control) sites, as well as for different treatment types using analysis of variance 238 and Tukey's multiple comparison tests. Data was also collected on the residual tree 239 population. Equation (2) was also used in computing basal proportion of green trees i.e. 240 residual trees. 
242 We used an approach where mean damage is either reduced or increased by modifiers

243 (Eqn. 3).

$244 \quad[3] \quad W=\bar{W} \prod_{i=1}^{n} f_{i}\left(x_{i}\right)$

245 where $W$ is estimated damage, $\bar{W}$ is mean damage estimated from the calibration data set

246 and $f_{i}\left(x_{i}\right)$ denotes the product of $n$ modifiers of selected explanatory variables $x_{1}$ to $x_{n}$

247 (Eqn. 4) .

248

[4] $f_{i}\left(X_{i}\right)=1+\beta_{l . X i}\left(\frac{X_{i}-\bar{X}_{i}}{\bar{X}_{i}}\right)+\beta_{q . X i}\left(\frac{X_{i}-\bar{X}_{i}}{\bar{X}_{i}}\right)^{2}$

249 where $\beta_{I . x_{i}}$ and $\beta_{q . X_{i}}$ represent the linear and quadratic effects of the variables $X_{i}$ on

250 windthrow damage. We introduced a random error ( $s$ ) component into Eqn. (3) to verify

251 if, besides selected fixed effect variables, there were substantial random effects of either

252 site or block or even plot and hence Eqn. (5). NLMIXED procedure was used (SAS

253 Institute, Cary, NC).

$254 \quad[5] \quad W=(\bar{W}+s) \prod_{i=1}^{n} f_{i}\left(X_{i}\right)$

255 Since the study design was such that we had treatment at two spatial scales, two sets of

256 models were calibrated; i) a plot-level model that first accounted for plot-level treatment

257 effects and ii) a block-level model with block-level treatment effects as first entry

258 variable. Through a stepwise procedure with forward selection, other plot-level variables

259 were introduced into the model and, for a variable to be retained in the model, it had to be

260 significant $(\alpha=5 \%)$, contribute substantially $(>1 \%)$ to total variance explained (Anyomi et 
261 al., 2015) and its entry into the model needed to be associated with significant reduction

262 in AIC values $(>2)$. Additionally, a variable is retained when it contributes the highest, to

263 the total variance explained relative to the other candidate explanatory variables

264 considered.

265 Because variables occur at block, and plot levels, the modifier approach and the stepwise

266 procedure enabled verifying if a concurrent and interactive effect drives windthrow

267 damage or whether spatial effects are mutually exclusive. Finally, we also determined if a

268 plot-level model was adequate in predicting the same results as a multiple-scale model.

269 The fit statistics (AIC, coefficient of determination and RMSE) of the two models were

270 considered. Treatment effects were compared using Tukey's HSD test. Statistical

271 analyses were carried out in SAS v9.3 (SAS Institute, Cary, NC) and JMP v12 (SAS

272 Institute, Cary, N.C.).

\section{$273 \quad 3.0$ Results}

$274 \quad 3.1$ Change in stand conditions following silvicultural treatments

275 Balsam fir was the most abundant species (65\%) in the study region with moderate black

276 spruce $(33 \%)$ and a few white birch $(2 \%)$ and white spruce $(<1 \%)$. Only minor changes in

277 species composition occurred after harvesting. Basal area was reduced by about $87 \%$

278 under CPRS, 72\% under CPPTM, and by about $45 \%$ and $40 \%$ respectively under SC1

279 and SC2. Structure was also strongly simplified by CPRS and CPPTM.

\subsection{Importance of different mortality types}

281 After about 6-7 years of post-harvest monitoring, mortality was observed to be highest in 282 heavily cut plots $(62 \%, 56 \%$ respectively for CPPTM and CPRS) and lower on selection 
283 cuts sites $(38 \%, 28 \%$ for SC1 and SC2, respectively) as well as on control plots (18\%).

284 Overall, a higher proportion of standing dead (24\% s.d.: 21) trees was observed compared 285 to windthrown trees $(12 \%$, s. d.: 17$)$. However, the proportion of standing dead and wind286 driven damage were correlated $(\mathrm{r}=0.78, \mathrm{p}=0.000)$ and the pattern was similar by block287 and plot-level treatments as well as by species (results not shown) suggesting that for our 288 study region, windthrow and standing dead dynamics might have common facilitating 289 factor(s). Results also show insignificant differences in green-tree basal area proportion 290 between CPRS and CPPTM ( $\mathrm{p}=0.799)$ sites (Fig. S1A). Residual basal area proportion 291 was higher on selection cut sites as well as control sites (Fig. S1A \& S1B). Total absolute 292 post-harvest mortality was lowest for heavy cut sites compared to selection cut plots (Fig. 293 S1C \& S1D).

\subsection{Variables retained in models at plot and block levels}

295 3.3.1 Plot-level model

296 Plot-level treatment effect accounted for $7 \%$ of variability in windthrow (AIC $=537$ ).

297 Stand mean dbh contributed $28 \%$ to total variance explained, reducing model AIC by 18.

298 Balsam fir basal area proportion further reduced model AIC by 3, contributing an 299 additional $7 \%$ to variance explained. The final plot-level model is thus:

300

[6] $W_{p}=\left[\bar{W}_{p}+\sum_{i=1}^{n}\left(\beta_{p . i} \times z_{p . i}\right)\right] \times f_{\overline{d b h}} \times f_{\text {Gbalsamf }}$

301 Where $\bar{W}_{p}$ is plot-level mean basal area proportion damaged by wind, $z_{p . i}$ is a binary 302 variable referring to plot-level treatment and $\beta_{p . i}$ is the effect of this plot-level treatment, 
303 and $f_{\overline{d b h}}, f_{\text {GBalsamf }}$ are modifiers linked to stand mean dbh and balsam fir basal area 304 respectively. Model parameter values are in Table 3.

305 $<<<$ Table $3>>>$

\subsubsection{Block-level model}

307 Block-level treatment explained most of the variability $\left(\mathrm{R}^{2}=48 \%\right)$ in windthrow levels 308 (with AIC value of 450). Balsam fir basal area proportion was the second explanatory 309 variable retained in the model, reducing AIC by 11 and contributing $13 \%$ to the total 310 variance explained. Eqn. 6 thus explains $61 \%$ of variability in windthrow at the block 311 level.

$$
\text { [7] } W_{B}=\left[\bar{W}_{B}+\sum_{i=1}^{n}\left(\beta_{B . i} \times z_{B . i}\right)\right] \times f_{\text {Gbalsamf }}
$$

$313 \bar{W}_{B}$ is block-level mean basal area proportion damaged by wind, $z_{B . i}$ is a binary variable 314 referring to block-level treatment and $\beta_{B . i}$ denotes effect of this block-level treatment. $315 f_{\text {Gbalsamf }}$ is the modifier linked to balsam fir basal area proportion. This model is 316 essentially a hierarchical model since silvicultural treatments were at block level and 317 balsam fir basal area proportion is a stand-level variable. Parameter values of the block318 level model (Eqn. 7) can be found in Table 3.

319 Overall, Eqn. 7 explained $61 \%$ of variability in windthrow at the block level and has AIC 320 of 439 and the plot-level model (Eqn. 6) explained $42 \%$ of variability in windthrow at the 321 plot level with AIC of 516. 


\section{3.4.1 Plot-and block-level treatment effects on windthrow levels}

324 Multiple comparison tests show that basal area proportions windthrown at the plot level

325 was significantly higher in treated plots compared to control plots (Fig. 2A). Overall,

326 windthrow does not differ between CPPTM and CPRS treated plots ( $p=0.779$, Fig. 2A).

327 SC1 also led to higher losses in comparison with SC2. Windthrow also significantly

328 differed by block-level treatment, differences among treatment being similar to those

329 associated to the plot level (Fig. 2B).

$330<<<$ Fig. $2>>>$

331 Standing dead mortality responded to treatment quite similarly to windthrow. Tukey HSD

332 tests show that the proportion of standing dead trees was similar $(\mathrm{p}=0.395)$ between

333 CPPTM and CPRS for plot-level treatments. Significant differences were however

334 observed when compared to other plot-level treatments and also when compared to

335 control/background tree death (Fig. 3A). Similarly at the block level, proportion of

336 standing dead trees varied significantly from one treatment type to another except

337 between CPPTM and CPRS ( $\mathrm{p}=0.925$, Fig. 3B).

$338<<<$ Fig. 3>>>

339 3.4.2 Effect of balsam fir proportion on windthrow

340 Balsam fir basal area proportion was observed to be positively linked to wind damage

341 (Fig. 4).

$342<<<$ Fig. $4>>>$

$343 \quad 3.4 .3$ Effect of diameter 
344 As a single variable, diameter was weakly and negatively correlated with windthrow $345\left(\mathrm{p}=0.0025, \mathrm{R}^{2}=0.003\right)$, but after controlling for the effects of treatment, the effect of

346 diameter on windthrow levels exponentially increased $\left(\mathrm{R}^{2}=0.28\right)$ and became positive.

347 This explains why diameter is the second retained variable in the plot-level model. With 348 the block-level model, even though mean diameter was still significantly correlated to 349 windthrow, its contribution to the overall explained variability in windthrow was 350 relatively low, hence not retained in the final model.

\section{3.4.4 Effect of adjacent stands on the amount of windthrow}

352 The fact that the block-level model was more accurate suggests that the surrounding area 353 characteristics may also play an important role. Windthrow proportion was lower (12\%) 354 at the plot level compared to the block level (18\%). To further illustrate this pattern, we 355 compared windthrow for different block-level treatments (matrices) for plots that were 356 treated to SC 1 and SC2 (Fig. 5). Results suggest that blocks treated to heavy cut types 357 showed higher windthrow (Fig. 5).

$358<<<$ Fig. 5>>>

\section{$359 \quad$ 3.4.5 Site variables}

360 Most of the site variables considered in this study were not significantly correlated with 361 windthrow $(\mathrm{p}=0.202, \mathrm{p}=0.278, \mathrm{p}=0.112$ respectively for latitude, longitude and Topex). 362 Altitude significantly $(\mathrm{p}<0.0001)$ explained about $2 \%$ of the variability in windthrow.

363 However, altitude was not retained in any of the final models because after accounting 364 for silvicultural treatment effects and stand structural variables, the effect of altitude was 365 relatively weak. 


\section{4.0 Discussion}

367 4.1 Mortality levels

368 Mortality levels in this study were high, even in control stands. If such levels were 369 sustained over time, complete canopy destruction would occur within 35 years. Previous 370 studies in the region have found that the standing volume of these old forests fluctuates 371 over time around some relatively stable level (Garet et al. 2009). In our case, an episode 372 of wet snow occurred the year before the first blocks were treated. Even though stands

373 with severe damage were avoided, it remains possible that some trees were weakened by 374 this episode, leading to high amounts of trees that simply died standing. In the same 375 region, dendrochronological studies by Girard et al. (2014) have identified long periods 376 of low mortality, followed by important windthrow episodes starting in the 1990s. Such a 377 pattern may be occurring here.

\section{$378 \quad 4.2$ Mortality types}

379 Much of the mortality was composed of trees that simply died standing. According to 380 Bose et al. (2014), the increased wind penetration after harvesting would increase 381 evapotranspiration, leading to water stress and eventually tree death. Both types of 382 mortality were closely correlated and responded similarly to treatments. This fact could 383 indicate that they were governed by the same underlying factors. The studied stands were 384 old stands containing many trees of low vigor that were predisposed to die, whether still 385 standing or damaged by wind. The fact that overall mortality reached around $20 \%$ after 386 six to seven years probably reflects this. However, it must be emphasized that both types 387 of mortality show additive treatment effects with no compensation through a change in 388 mortality type. 
390 Treatment, both at the plot and block level, had a strong impact on both windthrow and

391 standing dead proportions, both being higher under heavy cutting systems (CPRS and

392 CPPTM) relative to selection cutting systems. Indeed, heavy cuts did not differ from each

393 other and produced twice as much windthrow as was observed under the selection cutting

394 systems (Fig. 2A and 3A). Selection cutting systems, particularly SC2 retains the most

395 overall living basal area and thus best meets the management objective of retaining old-

396 growth attributes.

397 Treatment effects largely reflect differences in harvesting intensity. Higher cutting

398 intensity is linked to increased wind penetration into the stand as inter-tree spacing

399 increases (Gardiner et al. 1997). This in turn translates into higher turning moments on

400 residual trees. Achim et al. (2005a) reported reduced critical wind speeds (Their Fig. 3b)

401 for both overturning and breakage following commercial thinning that removed $30 \%$ of

402 stand basal area in stands dominated by balsam fir.

403 In addition to cutting intensity, the spatial pattern of harvesting can have an impact on

404 windthrow levels. Hence, selection cut type 2 produced significantly lower vulnerability

405 to both types of mortality than selection cut type 1 (Fig. 2A, 2B, S1C \& S1D), even if

406 both harvested comparable amounts of basal area. In SC1, intensive logging is

407 concentrated in narrow strips along skid trails at any given harvesting time while with

408 SC2, only $25 \%$ of total basal area is removed at a time along skid trails. With a high local

409 harvesting rate, wind is able to penetrate more deeply into the stand, increasing

410 windthrow losses. Thorpe et al. (2008) found that stems close to skid trails were 
411 particularly vulnerable to windthrow. A higher cutting intensity close to skid trails could

412 thus lead to increased windthrow since it would tend to funnel wind within these areas.

413 Stand structure has been suggested to influence windthrow levels. In old-growth stands of

414 West Switzerland, Hanewinkel et al. (2014) observed low storm damage following a

415 major storm event (Lothar), which was attributed to the uneven-aged structure of the

416 forest. Bonnesoeur et al. (2013) also observed higher wind firmness within stands

417 managed under a coppice-with-standards system, in comparison with stands of a simpler

418 structure. Through a modeling exercise, Mason (2002) also concluded that irregular

419 stands should be more windfirm. Heavy partial cuts tend to homogenize forest structures

420 while selection cuts produce attributes similar to old-growth forests (Bose et al. 2014). In

421 our case, treatments have an effect on both stand density and structure. Selection cutting

422 treatments had stand structure diversity indices quite similar to control stands (Shannon

423 evenness indices of $0.830,0.816,0.877$ respectively for SC1, SC2 and Control) but still

424 experienced very different levels of mortality (Fig. S1C \& S1D). This suggests that

425 cutting intensity had a stronger impact on mortality than did stand structure. This

426 observation is further demonstrated by the lower AIC values for treatment effects (498)

427 when compared to the effects of Shannon evenness index (517).

4284.4 Influence of stand characteristics on windthrow levels

429 Balsam fir basal area proportion was observed to be positively linked to wind damage

430 (conferring higher vulnerability). Within eastern boreal forests, balsam fir proportion

431 increases with succession (Bouchard et al. 2008) and it is a relatively less stable species

432 when compared to other species e.g. black spruce (Ruel, 2000). For a given stem mass,

433 resistance to uprooting of balsam fir and black spruce is quite similar but crown 
434 characteristics differ (Achim et al. 2005b, Elie and Ruel 2005). The high incidence of

435 butt and root rot in balsam fir at old age could have a marked influence on the higher

436 vulnerability of the species to windthrow (Whitney 1989). Plot mean diameter was also

437 observed to be a positive predictor of windthrow. Diameter often correlates with height

438 and an increase in damage with height has often been observed (Ruel 1995). In addition,

439 diameter can reflect age and a higher incidence of rot is normally found at old ages.

440 However, given that the effect of diameter on windthrow was weak at the block level, it

441 suggests that, at the plot level, diameter effects reflect the inter-stand differences owing

442 to the silvicultural treatments not captured by the treatment variable in the plot-level

443 model.

\section{$444 \quad 4.5$ Influence of neighbouring stand characteristics on windthrow levels}

445 One of our objectives was to determine the role of multiple-scale factors on windthrow

446 vulnerability. Mortality across treatments generally followed the same trend at the plot

447 and the block levels. Results show that changing the spatial scale did not lead to a

448 substantial change in the windthrow predisposing factors, it however did change their

449 relative importance (Table 3). At both plot and block levels, lower levels of windthrow

450 were observed under selection cuts relative to heavy partial cuts and the strength of this

451 relationship was higher at block level $\left(\mathrm{R}^{2}=0.48\right)$ when compared to plot level $\left(\mathrm{R}^{2}=0.07\right)$.

452 At the block level, study plots were located in an environment treated the same way as

453 the plots. In contrast, at the plot level, a study plot could be located in an environment

454 submitted to a completely different treatment type. These findings are consistent with

455 results of Ruel et al. (2003) who reported that the characteristics of stands surrounding

456 partial cuts could have an effect on the amount of windthrow. 
457 The fact that after accounting for block-level treatment effects on mortality, significant

458 effects of plot-level basal area proportions contributed by balsam fir was observed (Eqn.

459 6) shows concurring effects of multiple-scale factors. Site variables (altitude, topographic

460 exposure) were largely insignificant in explaining windthrow patterns because of the

461 relatively uniform landscape of this study region (Table 2). Considering the higher

462 proportion of explained variance (61\%) that is associated with the block-level model, it

463 should be preferable for forecasting windthrow. For operational purposes however, a

464 plot-level model should be adequate in understanding mortality dynamics given the

465 similarity in the driving factors.

5.0 Implications for forest management

467 Heavy cuts (CPRS and CPPTM) are widely practiced in eastern Canadian boreal forests, 468 and here we observed that these are associated with twice as much post-treatment relative 469 damage as selection cuts. With CPRS, this high level of mortality, combined with the low 470 basal area left after harvesting, means that there remains very little canopy at the end of

471 the study (Fig. S1). Retention in clearcuts has been promoted as a way to include

472 structural elements in a regenerating stand. In some cases, these elements are expected to 473 be maintained over a full rotation (Mitchell and Beese, 2002) but high levels of

474 windthrow could compromise this objective. Even though the retained elements could be 475 expected to contribute to dead wood input, their role could be limited if high mortality

476 occurs within a short period of time after harvesting. From a stand production perspective

477 however, the fact that a substantial proportion of residual basal area is damaged from

478 windthrow under CPRS, does not become a concern because the overstory residual trees

479 are not expected to contribute to the yield of the next rotation. Group retention, targeting 
480 black spruce stands or portions of stands with a well-developed structure, has been

481 suggested as a means to reduce windthrow damage in clearcut stands (Lavoie et al. 2012).

482 With CPPTM, the amount of mortality remains high in relative terms but not in absolute

483 terms (Fig. S1C \& S1D). Given a larger residual basal area left after harvesting with this

484 treatment, the canopy finally remaining is higher than with CPRS (Fig. S1A \& S1B).

485 Also, residual trees are expected to enable a 10 year reduction of the normal rotation but,

486 considering the combined effects of the two mortality types (Fig. 2, 3, S1C \& S1D),

487 losses become a major concern.

488 Selection cuts enable minimizing relative windthrow damage (Fig. 2) but not absolute

489 damage (Fig. S1C \& S1D). They also maintain the densest canopy levels at the end of the

490 study. Selection cut sites thus present better opportunities for foraging, cavity nesting

491 birds, mammals and therefore biodiversity conservation (Knapp, 2015; Nappi et al. 2015).

492 However, selection cuts are associated with rather high implementation costs relative to

493 heavy cuts (Moore et al. 2012) and losses remain high, especially considering the slow

494 growth rate in these northern environments. Reducing windthrow losses associated with

495 CPPTM and selection cuts therefore becomes critical in enhancing the overall

496 profitability of these strategies.

497 Results also suggest that block-level interventions correlate better to mortality relative to

498 plot-level interventions, showing that the environment surrounding the partially harvested

499 area must be carefully considered. Partially cut stands should be located within portions

500 of uncut or partially cut forests rather than close to clearcuts.

501 Finally, tools (Eqn. 5 and 6) developed in this study could assist managers in identifying

502 areas of high vulnerability to windthrow, either at the stand or harvesting unit level. With 
503 a proper selection of stands to be treated and consideration of the effect of neighbouring 504 stands, losses could therefore be reduced.

\section{Conclusion}

506 This study examined windthrow levels at multiple scales after various levels of

507 harvesting. Mortality increased in direct relation with cutting intensity. Mortality was

508 also a function of diameter and species composition. Since treatment had an effect on

509 stand structure, no additional effect of stand structure (Shannon evenness index) could be

510 detected.

511 Wind damaged trees and trees that died standing responded, similarly suggesting a

512 common driver without compensation. Even though the low vigour of the stands could

513 play a role, this factor would more likely lead to some form of compensation, the less

514 vigorous trees that would die standing being also more likely to break or uproot. The

515 absence of compensation between mortality types would require further investigation.

516 Among the two models developed, the one using both variables coming from the stand

517 (stand total basal area composition contributed by balsam fir species) and block levels

518 (treatment) proved superior. This means that a gain in precision can be obtained when

519 considering multiple scales for windthrow hazard estimation. However, since both

520 models retained the same variables, a model developed from the monitoring of individual

521 plots still provides a valuable approach to derive a relative estimate of windthrow

522 vulnerability.

523 In this study, very high levels of mortality were observed, even in control stands. Such

524 levels may have been influenced by individual weather events that occurred just prior to

525 the study establishment or during the monitoring period. The models that were developed 
526 here provide some useful insights into how to reduce losses in future applications. Lower

527 cutting intensity located within portions of uncut or partially cut forests, and targeting

528 balsam fir for removal should be tested.

\section{References}

530 Achim, A., Ruel, J.-C., Gardiner, B.A. 2005. Evaluating the effect of pre-commercial 531 thinning on the resistance of balsam fir to windthrow through experimentation, 532 modelling, and development of simple indices. Canadian Journal of Forestry 533 Research 35: 1844-1853.

534 Achim, A., Ruel, J.-C., Gardiner, B.A., Laflamme, G., Meunier, S. 2005b.Modelling the 535 vulnerability of balsam fir forests to wind damage. For. Ecol. Manage. 204: 35-50.

Anyomi, K.A., Lorenzetti, F., Bergeron, Y., Leduc, A. 2015. Stand Dynamics, Humus Type and Water Balance Explain Aspen Long Term Productivity across Canada. Forests 6: 416-432.

Bouchard, M., Pothier, D., Gauthier, S. 2008. Fire return intervals and tree species succession in the North Shore region of eastern Quebec. Canadian Journal of $554 \quad$ Forestry Research 38 : 1621-1633. 
Boucher D., De Grandpré L., Gauthier S. 2003 Développement d'un outil de classification de la structure des peuplements et comparaison de deux territoires de la pessière à mousses du Québec. Forestry Chronicle 79: 318-328.

Boucher, D., Gauthier, S, De Grandpré, L. 2006. Structural changes in coniferous stands along a chronosequence and productivity gradient in the northeastern boreal forest of Québec. Ecoscience 13(2): 172-180.

Cimon-Morin, J., Ruel, J-C., Darveau, M. 2010. Short term effects of alternative silvicultural treatments on stand attributes in irregular balsam fir-black spruce stands. Forest Ecology and Management 260 (5): 907-914.

Elie, J-G., Ruel, J-C. 2005. Windthrow hazard modelling in boreal forests of black spruce and jack pine. Canadian Journal of Forestry Research 35: 2655-2663.

Fortin M., Bernier S., Saucier J-P., Labbé F., 2009. Une relation hauteur-diamètre tenant compte de l'influence de la station et du climat pour 20 espèces commerciales du Québec. Ministère des ressources naturelles et de la faune du Québec, Mémoire de recherche forestière No 153

Gardiner, B.A., Stacey, G.R., Belcher, R.E., Wood, C.J. 1997. Field and wind tunnel assessments of the implications of respacing and thinning for tree stability. Forestry, 70: $233-252$.

Garet, J., Pothier, D., Bouchard, M., 2009. Predicting the long-term yield trajectory of black spruce stands using time since fire. Forest Ecology and Management 257: 2189-2197.

Gendreau-Berthiaume, B., Kneeshaw, D.D., Harvey, B.D. 2012. Effects of partial cutting and partial disturbance by wind and insect on stand composition, structure and growth in boreal mixedwoods. Forestry 85: 551-565.

Girard, F., DeGrandpré, L., Ruel, J.-C., 2014. Partial windthrow and forest dynamics in the eastern boreal zone of Quebec, Canada. Can. J. For. Res. 44: 1165-1176.

Groot A., Lussier J.-M., Mitchell A.K., MacIsaac D.A. 2005. A silvicultural systems perspective on changing forestry practices. Forestry Chronicle 81: 50-55.

Hanewinkel, M., Kuhn, T., Bugmann, H., Lanz, A., Brang, P. 2014. Vulnerability of uneven-aged forests to storm damage. Forestry $0: 1-10$. 
Knapp, E.E. 2015. Long term dead wood changes in a Sierra Nevada mixed conifer forest: Habitat and fire hazard implications. Forest Ecology and Management 339: 87 - 95.

Lavoie, S., Ruel, J.-C., Bergeron, Y., Harvey, B. D. 2012. Windthrow after group and dispersed tree retention in eastern Canada. Forest Ecology and Management 269: 158-167.

Létourneau, J.-P., Bard, A., Lambert, J. 2003. Normes de cartographie écoforestière. Troisième inventaire écoforestier. Ministère des Ressources naturelles, de la faune et des Parcs, Direction des inventaires forestiers, Québec. http://www.mrn.gouv.qc.ca/publications/forets/connaissances/normecartographieecoforestiere. Last accessed on 31.08.2013.

Long, J.N. 2009. Emulating natural disturbance regimes as a basis for forest management: A North American view. Forest Ecology and Management 257: 1868-1873.

Mason W.L. 2002. Are irregular stands more windfirm? Forestry 75 (4): 347-355.

Mitchell S.J., Beese W.J. 2002. The retention system: reconciling variable retention with the principles of silvicultural systems. Forestry Chronicle 78:397-403.

Moore, T.Y., Ruel, J.-C., Lapointe, M.-A., Lussier, J.-M. 2012. Evaluating the profitability of selection cuts in irregular boreal forests: an approach based on Monte Carlo simulations. Forestry 85: 64-77.

Nappi, A., Drapeau, P., Leduc, A. 2015. How important is dead wood for woodpeckers foraging in eastern North American boreal forests? Forest Ecology and Management 346, 10-21.

Régnière, J., Saint-Amant, R. 2008. BioSIM 9 - Manuel de l'utilisateur. Ressources naturelles Canada, Service canadien des forêts. Centre de foresterie des Laurentides. Rapport d'information LAU-X-134F. ftp://www.ftp.cfl.scf.rncan.gc. $\mathrm{ca} /$ regniere/Data/Weather/ Last accessed on 31.08.2013.

Ruel, J-C. 1995. Understanding windthrow: Silvicultural implications. Forestry Chronicle 71(4): 434 - 445.

Ruel, J-C. 2000. Factors influencing windthrow in balsam fir forests: from landscape studies to tree individual tree studies. Forest Ecology and Management 135: 169178. 
615

Ruel J.-C., Pin D., Spacek L., Cooper K., Benoit R. 1997. The estimation of wind exposure for windthrow hazard rating: comparison between Strongblow, MC2, Topex and a wind tunnel study. Forestry 70: 253-265.

Ruel J.-C., Pin D., Cooper K. 1998. Effect of topography on wind behaviour in a complex terrain. Forestry 71: $261-265$.

Ruel, J-C., Achim, A., Herrera, R.E., Cloutier, A., Brossier, B. 2010. Wood degradation after windthrow in a northern environment. Forest Products Journal 60(2): 200-206.

Ruel, J.-C., Fortin, D. and Pothier, D. 2013. Partial cutting in old-growth boreal stands: an integrated experiment. Forestry Chronicle 89: 360-367.

Ruel, J.-C., Mitchell, S.J., Dornier, M. 2002. Mapping wind exposure for windthrow hazard mapping. NJAF 19 (4): 183-187.

Ruel, J.-C., Raymond, P., Pineau, M. 2003. Windthrow after shelterwood cutting in balsam fir stands. NJAF 20: 5-13

Stocks, B. J., Mason, J.A., Todd, J. B., Bosch, E. M., Wotton, B. M., Amiro, B. D., Flannigan, M. D., Hirsch, K. G., Logan, K. A., Martell, D. L., Skinner, W. R. 2003. Large forest fires in Canada, 1959-1997. Journal of Geophysical Research 107, 8149.

Thorpe, H. C., Thomas, S. C., Caspersen, J. P. 2008. Tree mortality following partial harvests is determined by skidding proximity. Ecological Applications, 18(7): $1652-1652$

Waldron, K., Ruel, J.-C.,Gauthier, S. 2013. The effects of site characteristics on the windthrow regime in a landscape scale of the North Shore region of Quebec, Canada. Forestry 86: 159-171.

Whitney, R.D. 1989. Root rot damage in naturally regenerated stands of spruce and balsam fir in Ontario. Canadian Journal of Forest Research 19(3) : 295 - 308. 


\section{LIST OF TABLES}

Table 1: Plot distributions under each of the plot (columns) and block (rows) level treatments

Plot level treatment

\begin{tabular}{llllll}
\hline Block level treatment & SC1 & SC2 & CPPTM & CPRS & Control \\
\hline SC1 & 16 & 3 & 3 & 3 & 3 \\
SC2 & 3 & 16 & 3 & 3 & 3 \\
CPPTM & 3 & 3 & 16 & 3 & 3 \\
CPRS & 3 & 3 & 3 & 17 & 3 \\
Control & 3 & 3 & 3 & 3 & 16 \\
\hline
\end{tabular}

Table 2: Variables considered in windthrow modelling, stand and site attributes after silvicultural treatment.

\begin{tabular}{lll}
\hline Variable & $\begin{array}{l}\text { Mean (standard dev.)/ } \\
\text { Number of Classes }\end{array}$ & Minimum, Maximum \\
\hline Treatment & 5 & - \\
\hline Stand structural variables & $10.77(1.80)$ & $6.48,13.61$ \\
\hline Stand mean height & $15.45(2.36)$ & $9.80,20.65$ \\
Stand mean DBH & $0.78(0.18)$ & $0,0.99$ \\
Shannon Evenness Index & $31(12.10)$ & 1,54 \\
Number of trees per plot & & \\
& &
\end{tabular}

Species basal area compositions (\%) 


\begin{tabular}{lll}
\hline Balsam fir & $57.20(25.53)$ & 0,100 \\
Black spruce & $39.90(26.24)$ & 0,100 \\
White birch & $2.33(5.45)$ & 0,79 \\
White spruce & $0.06(0.63)$ & 0,7 \\
\hline Site variables & $50.88(0.33)$ & \\
\hline Latitude $\left({ }^{0} \mathrm{~N}\right)$ & $-68.85(0.60)$ & $-69.43,-67.98$ \\
Longitude $\left({ }^{0} \mathrm{~W}\right)$ & $548(50.97)$ & 454,656 \\
Altitude (m) & $0.90(10.41)$ & $-32.20,33.06$ \\
Topographic exposure (Topex) & & \\
\hline
\end{tabular}

Table 3: Model parameter estimates

Plot-level model Block-level model

\begin{tabular}{|c|c|c|c|c|}
\hline Variable & Parameter & Estimate (SE) & Parameter & Estimate (SE) \\
\hline \multirow[t]{5}{*}{ Treatment } & $\beta_{p . S c_{1}}$ & $-15.267(7.332)$ & $\beta_{b . S c_{1}}$ & $4.515(3.923)$ \\
\hline & $\beta_{p . s C_{2}}$ & $-13.335(7.702)$ & $\beta_{b . S c_{2}}$ & $-5.992(4.825)$ \\
\hline & $\beta_{p . C P P T M}$ & $25.761(11.429)$ & $\beta_{b . C P P T M}$ & $8.672(3.492)$ \\
\hline & $\beta_{p . C P R S}$ & $43.251(22.049)$ & $\beta_{b . C P R S}$ & $11.224(4.506)$ \\
\hline & $\beta_{p . C}$ & $-24.670(7.051)$ & $\beta_{b . C}$ & $-11.485(4.851)$ \\
\hline \multirow[t]{2}{*}{ Mean DBH } & $\beta_{\mid \overline{d b}}$ & $4.562(1.101)$ & & - \\
\hline & $\beta_{\mathrm{q} \overline{\mathrm{db}}}$ & $5.652(3.341)$ & & - \\
\hline
\end{tabular}




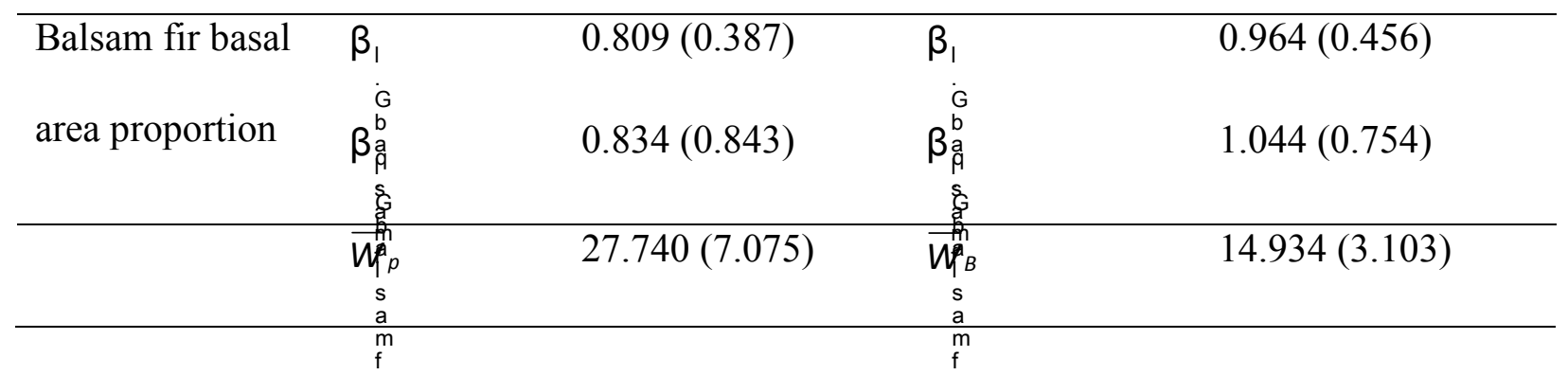




\section{LIST OF FIGURES}

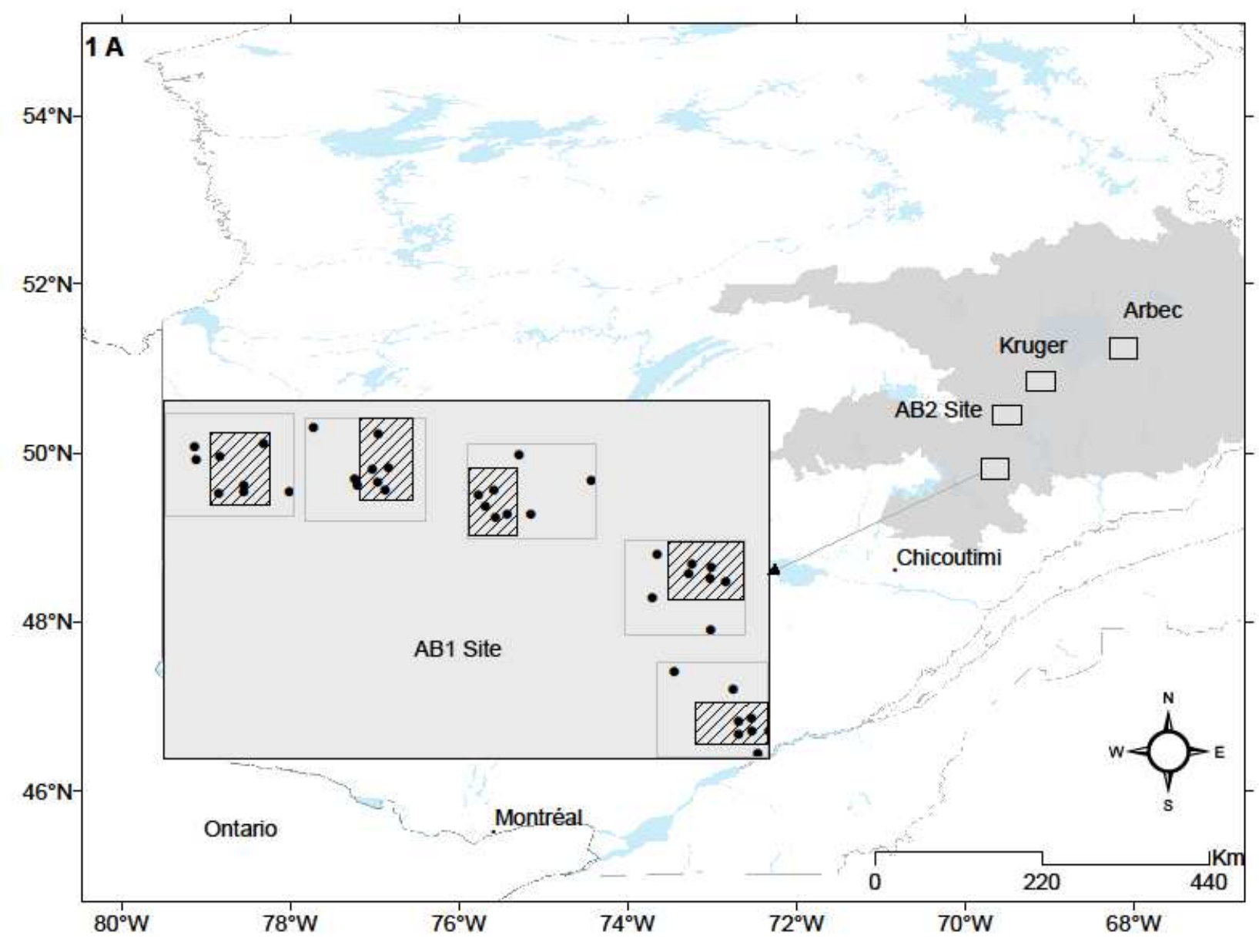

$1 \mathrm{~B}$
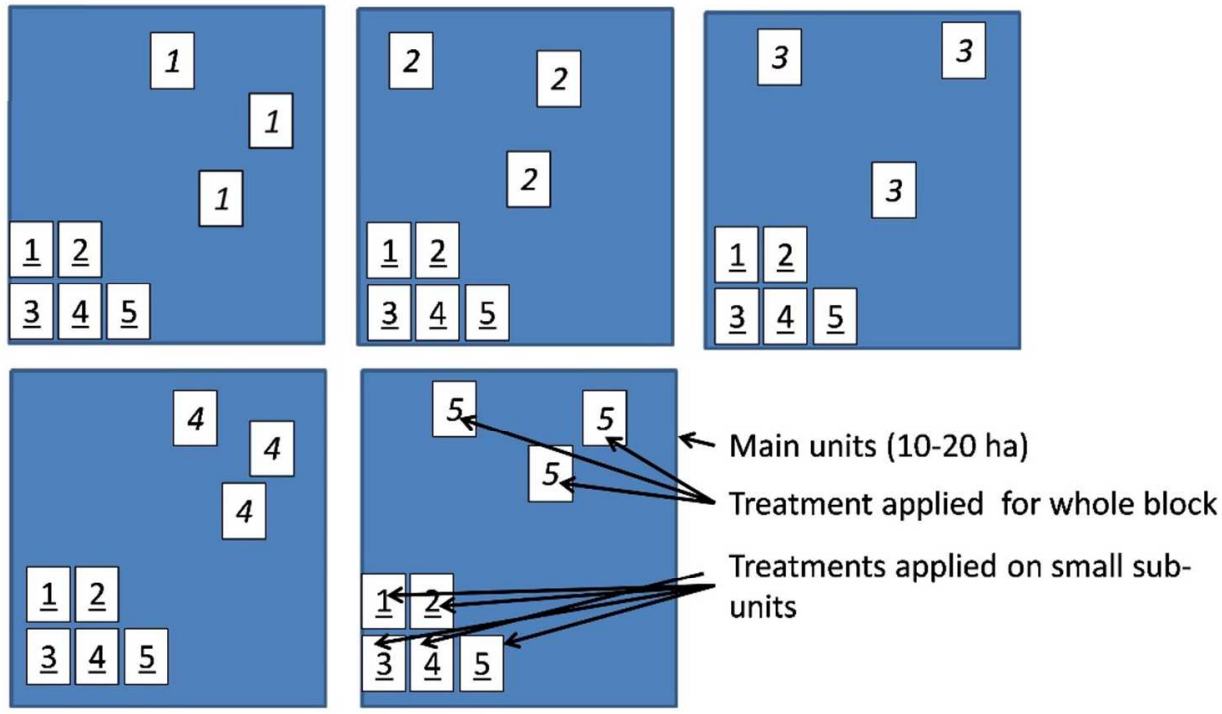
Fig. 1. A; Study area map showing the location of the four study sites and an illustration of plot distribution within a site. The hatchings highlight plot-level treatment within a block. The area outside the hatched zone is treated with a single treatment, corresponding to the block-level treatment. B; Schematic illustration of the experimental design showing the main (block-level) units and plot-layout within blocks. Selection cut type 1 is denoted by 1 , Selection cut type 2 by 2, CPRS is 3, CPPTM is 4 and Control is 5.
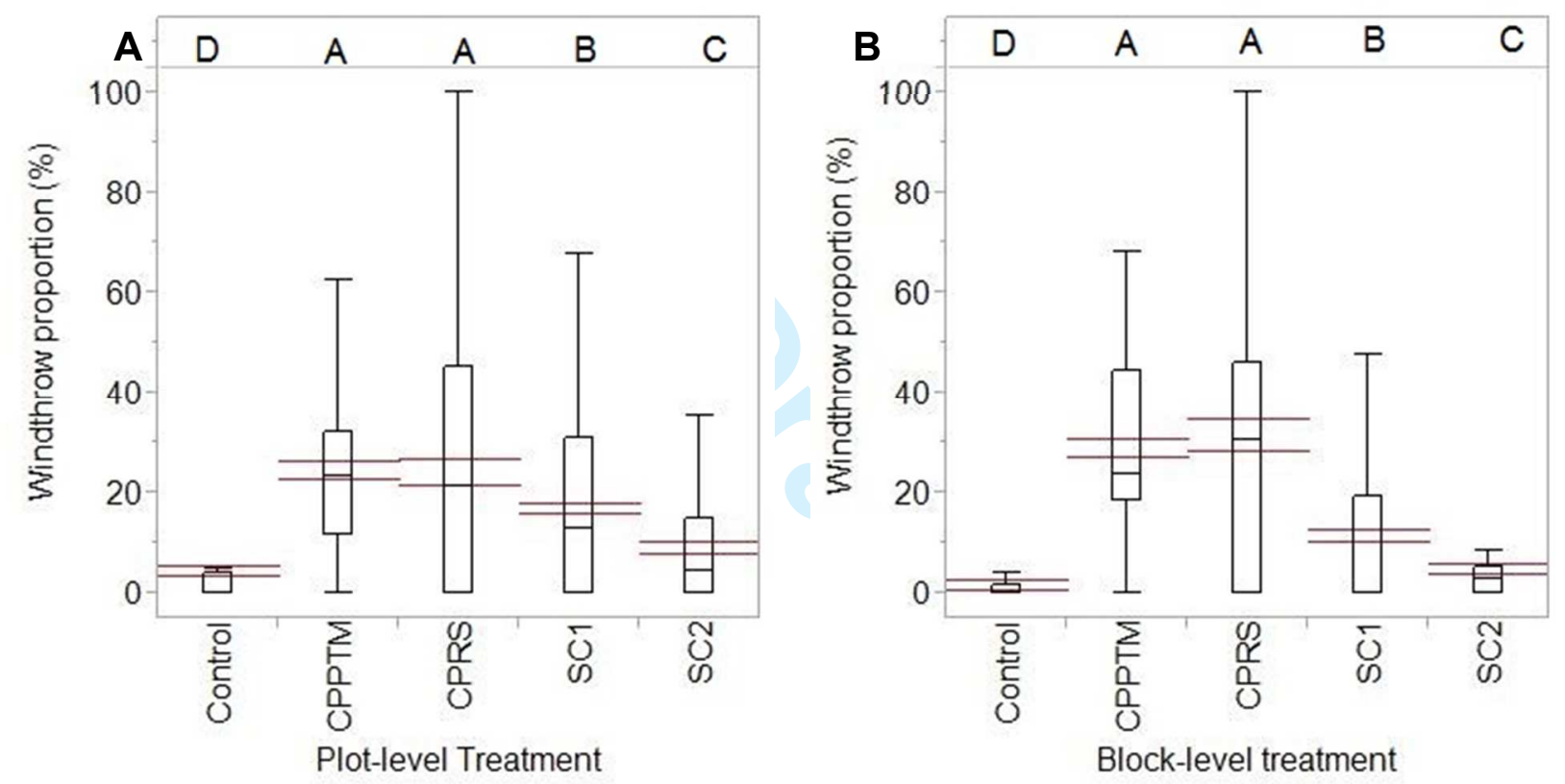

Fig. 2. Basal area proportion windthrown by $\mathbf{A})$ plot-level treatment and B) block-level treatment. Red lines indicate 95\% confidence interval of the mean. Means marked with same letters do not differ significantly (Tukey's HSD, $\alpha=5 \%$ ). 


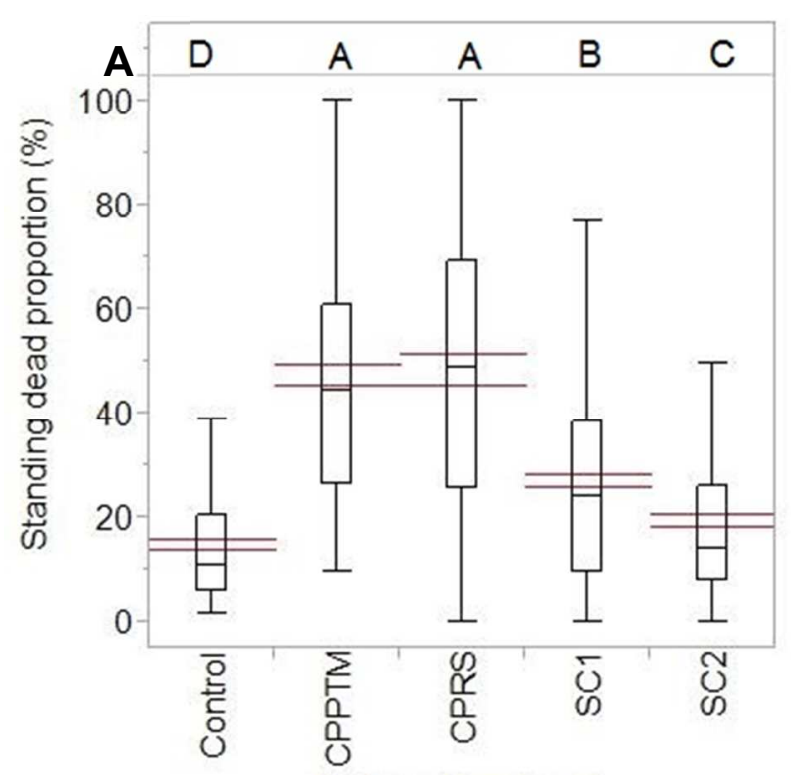

Plot-level treatment

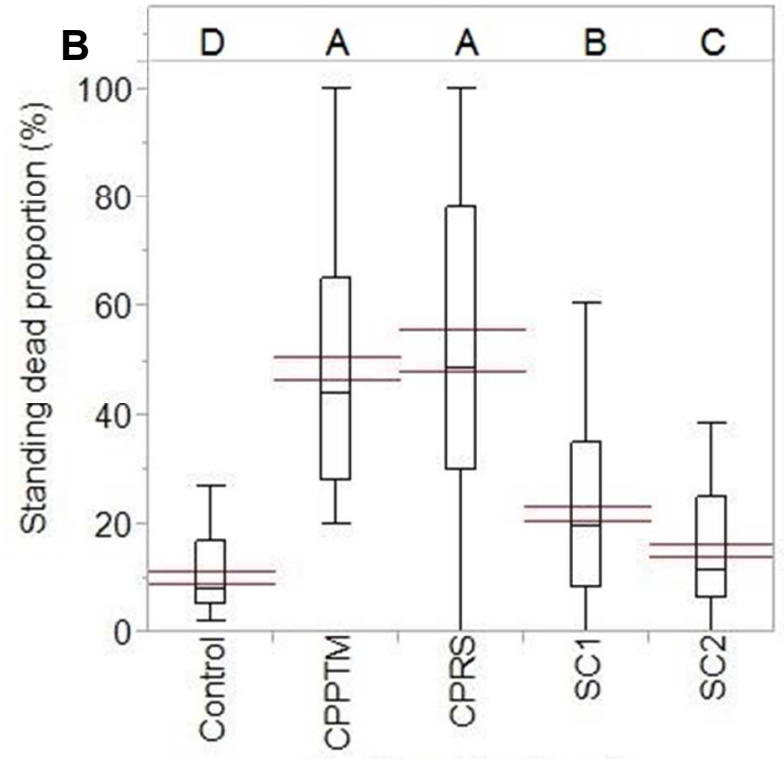

Block-level treatment

Fig. 3. Effect of A) plot-level treatment and B) block-level treatment on patterns of standing dead trees. Red lines indicate 95\% confidence interval of the mean. Means marked with same letters do not differ significantly (Tukey's HSD, $\alpha=5 \%$ ).

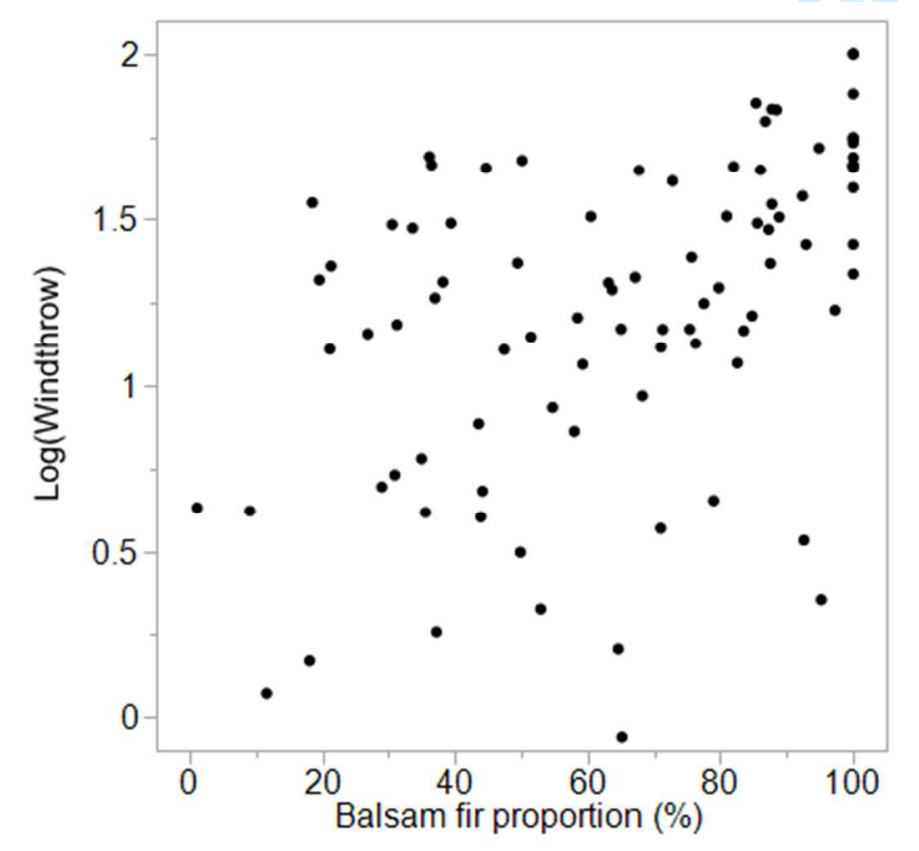

Fig. 4. Variability in windthrow levels $\left(\log _{10}\right.$ transformed) by the proportions of balsam fir within stands. 


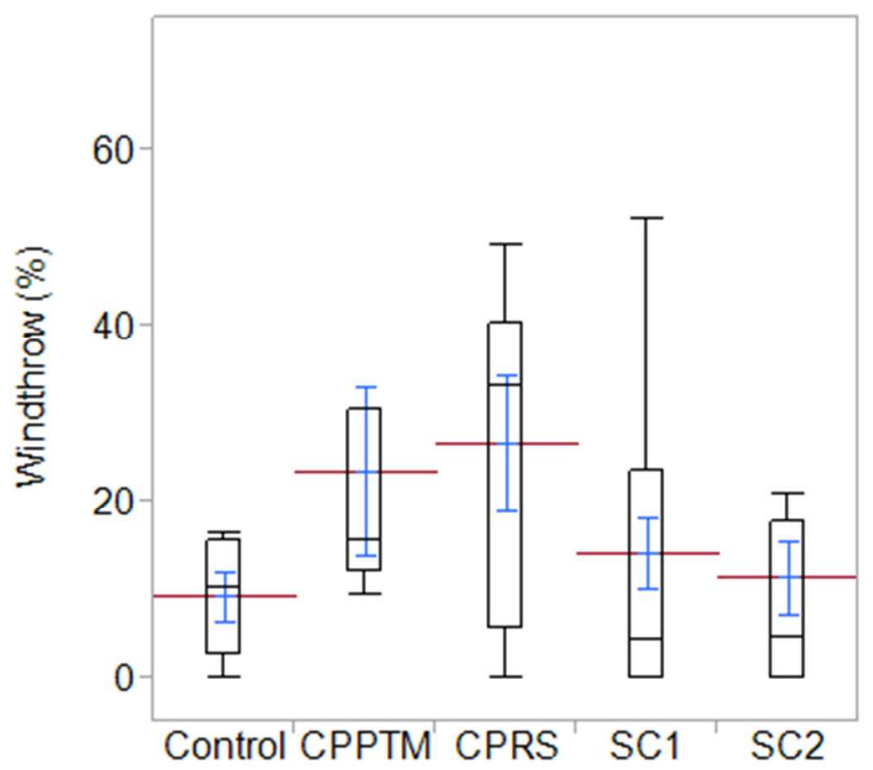

Fig. 5: Variation in windthrow levels within plots treated to selection cut and with adjacent stands treated to various treatment types. Adjacent stands that were heavily cut (CPPTM, CPRS), show higher windthrow levels. Red line denotes the mean windthrow and the blue indicates standard error of the mean.
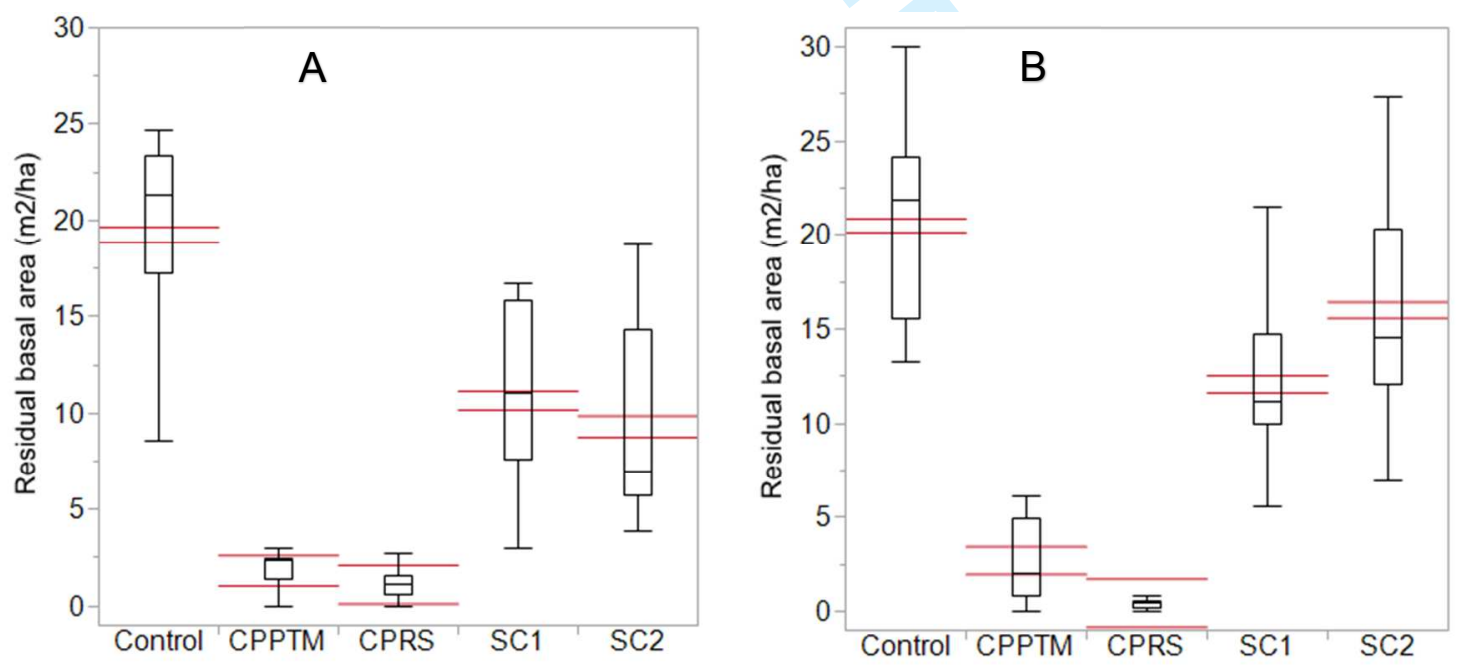


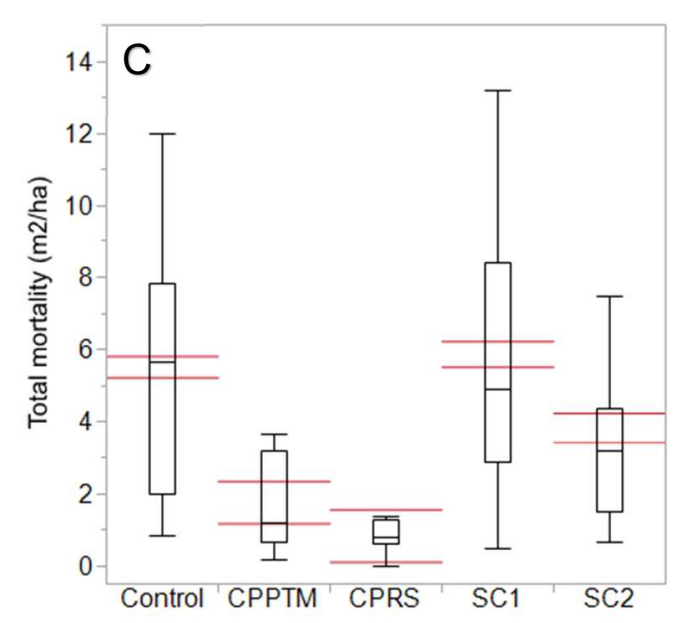

Plot-level

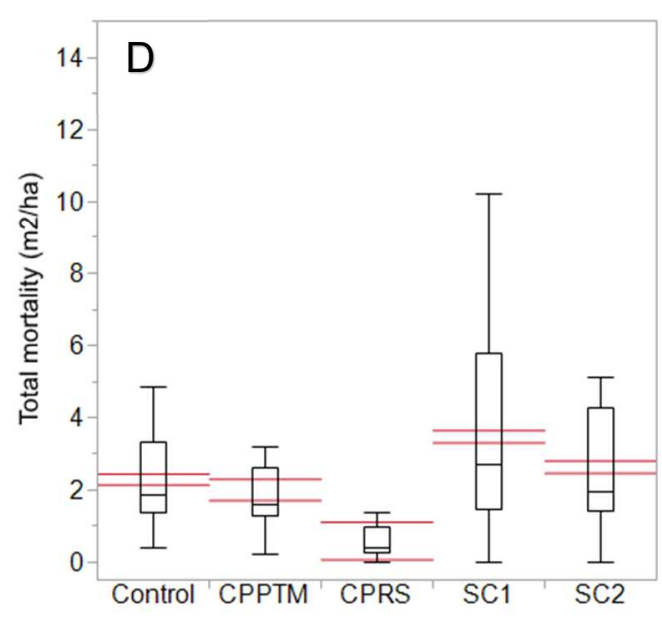

Block-level

Fig. S1. Living residual basal area by A) plot and B) block level treatments. Total absolute postharvest mortality at the C) plot and D) block levels. 